\title{
The deepest Moho in the Western Carpathians and its respective crustal density model (CEL12 section)
}

\author{
Dominika GODOVÁ ${ }^{1}$, Miroslav BIELIK ${ }^{1,2}$, Barbora ŠIMONOVÁ ${ }^{1}$ \\ ${ }^{1}$ Department of Applied and Environmental Geophysics, \\ Faculty of Natural Sciences, Comenius University, \\ Mlynská dolina, Ilkovičova 6, 84248 Bratislava, Slovak Republic; \\ e-mail: bielik@fns.uniba.sk \\ ${ }^{2}$ Earth Science Institute, Slovak Academy of Sciences, \\ Dúbravská cesta 9, P. O. Box 106, 84005 Bratislava, Slovak Republic; \\ e-mail: geofmiro@gmail.com
}

\begin{abstract}
The main aim of this study is to compile 2-D density model of the CELEBRATION 2000 profile CEL12, which is based on seismic refraction data. The profile CEL12 crosses the External Western Carpathians Flysch zone and is located in the southern part of Poland. The general feature of the resultant density model shows significant changes in the crustal thickness. The Moho depth changes in the interval from $31 \mathrm{~km}$ to $43 \mathrm{~km}$. The interpreted $43 \mathrm{~km}$ crustal thickness over a $60 \mathrm{~km}$ section of the profile results in the discovery of an area, which represents the thickest crust in the entire West Carpathians. This area is situated $\sim 50 \mathrm{~km}$ north-east from the High Tatras in Poland.
\end{abstract}

Key words: gravimetry, density modelling, seismic constraints, External Western Carpathians Flysch zone, CELEBRATION, Bouguer gravity

\section{Introduction}

The deep seated structure and dynamics of the Earth's lithosphere is one of the worldwide current research topics. The use of geophysical methods gives us advantage to expand our knowledge. Particularly seismics is one of the most used and most useful methods to describe the structure and composition of the Earth's crust. In last decades, many international projects, such as POLONAISE'97, CELEBRATION 2000, ALPS 2002 and SUDETES 2003 took place in the Central European region and contributed to very high level of survey coverage in this area (e.g. Guterch et al., 2003a; 
Grad et al., 2006; Środa et al., 2006; Hrubcová et al., 2005; 2010; Behm et al., 200\%; Brückl et al., 2010; Brückl, 2011; Janik et al., 2011; Malinowski et al., 2009, 2013).

For research in the Western Carpathians and their immediate surroundings, the CELEBRATION 2000 (Central European Lithospheric Experiment Based on Refraction 2000) project was the most important. The project was held by 28 European and North American research institutions and contained 16 seismic refraction profiles crossing the ALCAPA region (Guterch et al., 2003a,b). These profiles were focused to cover the most of the tectonic units in Central Europe, such as the East European Craton, the Trans European Suture Zone (TESZ), the Western Carpathians, the Pannonian Basin, the Bohemian Massif and the Eastern Alps.

Further information on the crustal and lithospheric structure of Europe have been published by Tesauro et al. (2008), Kaban et al. (2010), Jones et al. (2010), Plomerová and Babuška (2010), Zeyen et al. (2002), Dérerová et al. (2006), Grinč et al. (2013). Important knowledge about the depths of Moho and lithosphere-asthenosphere boundary (LAB) have also been obtained by integrative 3-D modelling (LitMod) combining in a self-consistent manner concepts and data from thermodynamics, mineral physics, geochemistry, petrology and solid Earth geophysics (Alasonati Tašárová et al., 2009, 2016).

With its length of nearly $200 \mathrm{~km}$, the seismic refraction profile CEL12 is one of the shortest profiles of the project CELEBRATION 2000. Located in the southern part of Poland (Fig. 1), it crosses exclusively the tectonic unit of the External Western Carpathians Flysch zone (Fig. 2). Despite of its short length, the main importance of this profile dwells in the fact that it crosses some of the other important CELEBRATION 2000 profiles. It contributes to result switchover between those profiles and broadens interpretation possibilities of the lithospheric structure in the Western Carpathians. The importance of the CEL12 profile lies above all in the discovery of the deepest Moho discontinuity (the thickest crust) in the Western Carpathian region.

The main aim of this study is to compile and interpret a 2-D density model along the seismic profile CEL12 based on the seismic refraction profiling results and other geophysical and geological constraining information. 


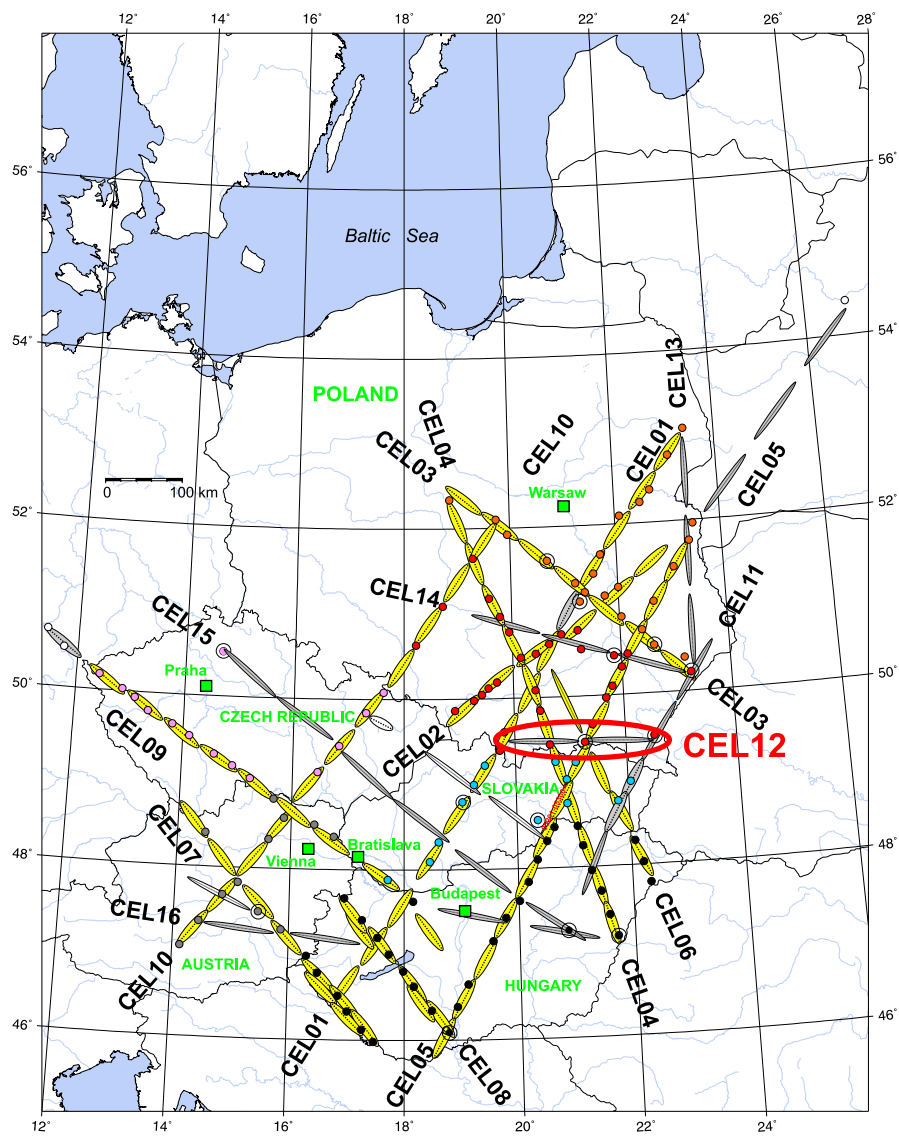

Fig. 1. Map of the CELEBRATION 2000 profiles (modified after Guterch et al., 2003a). The CEL12 profile is shown in red ellipse. The red, pink, blue, black, orange and grey color circles show shot points. Yellow lines are high density recording profiles, the other lines are low density recording profiles.

\section{Geological setting}

The CELEBRATION 2000 project crossed the Carpathian-Pannonian region, which is part of the ALCAPA microplate (including also the Transdanubic Range and the Eastern Alps). This area is subject to discussions regarding its structure and tectonic evolution (Janik et al., 2011). There are two main views about its Tertiary evolution. The first one suggests 
the gravitational collapse of the continental lithosphere (e.g., Knapp et al., 2005; Gemmer and Houseman, 2007). The second one regards as crucial the process of subduction of the oceanic lithosphere, which is more accepted for its geological and geophysical evidence (e.g., Csontos et al, 1992; Nemčok et al., 1998; Konečný et al., 2002; Alasonati Tašárová et al., 2009).

The Western Carpathians are a mountain range with dominant nappe structure and characteristic north-vergent orogenetic processes migration

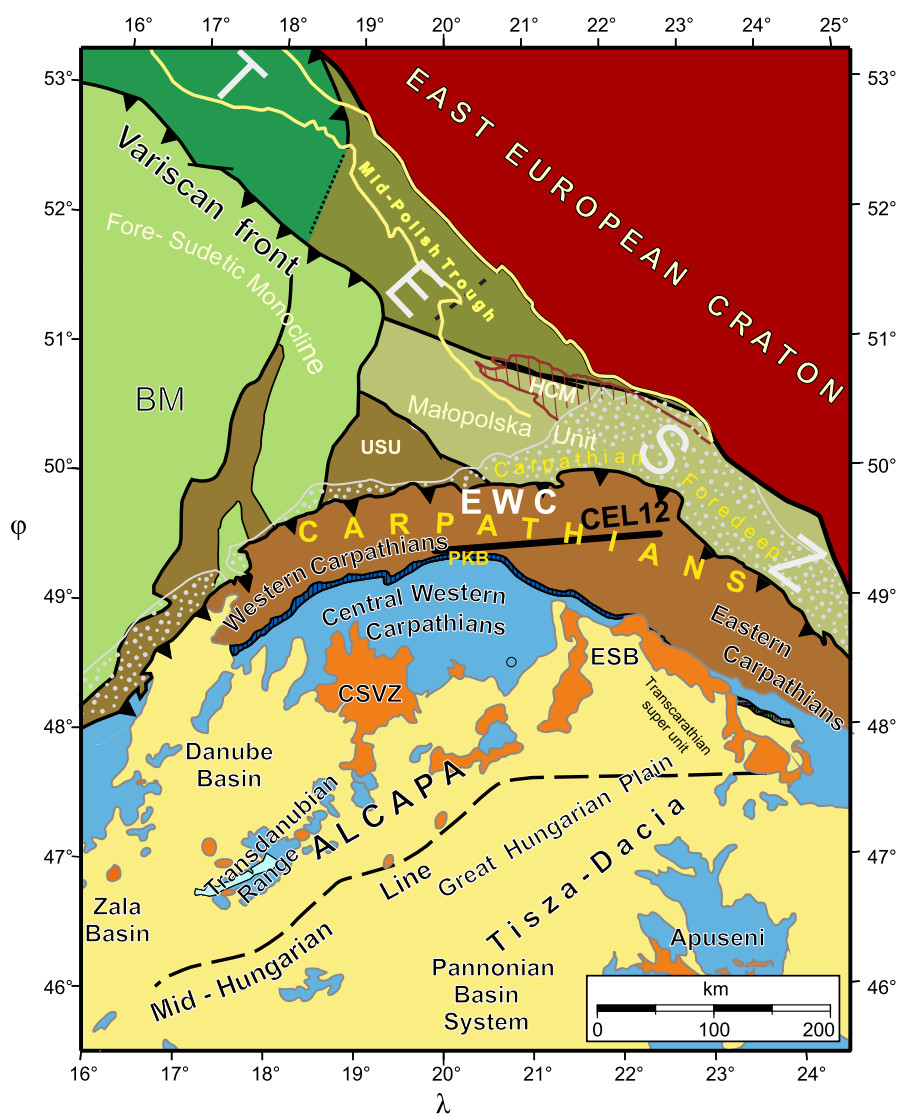

Fig. 2. Position of the CEL12 seismic profile on geological map of the Central Europe (modified after Janik et al., 2011). EWC - External Western Carpathians; HCM - Holy Cross Mts.; BM - Bohemian Massif; USU - Upper Silesian Unit; CSVZ - Central Slovak Volcanic zone; ESB - East Slovakian Basin; PKB - Pieniny Klippen Belt; TESZ - TransEuropean Suture Zone. 
(Alasonati Tašárová et al., 2009). The mountain range is circumscribed by the edge of alpine nappes in the north, Eastern Alps in the west, Uzh river valley in the east, while the southern boundary is poorly demarcated due to sedimentary cover of the Western Carpathian units (Hók et al., 2001, 2014). The Western Carpathians can be divided into the Internal Western Carpathians and External Western Carpathians (Mišik et al., 1985).

The seismic profile CEL12 is exclusively located in the External Western Carpathians (Fig. 2), which are separated from the Internal Western Carpathians by Pieniny Klippen Belt in the south (Oszczypko et al., 2015). The External Western Carpathians form a huge accretionary wedge with north-vergent nappe structure (Środa et al., 2006; Hók et al., 2014) composed of Cretaceous and Paleogene formations (Oszczypko, 2004). The basement is formed by the Epivariscan Platform with the thickness in range from hundreds to thousands meters beneath the Western Carpathians (Oszczypko, 2004). The Flysch zone has a typical development with the alternation of abyssal turbidity sediments (Kováč et al., 2016), more precisely shales and sandstones developing on the continental margins with thickness of sediments up to $18 \mathrm{~km}$ in the easternmost part (Rytko and Tomaś, 2005; Janik et al., 2011). The foreland was befallen by the subduction of the oceanic crust and lead to dying out of the basin of deposition from Upper Paleogene to Upper Miocene (Alasonati Tašárová et al., 2009) and successive detachment of the sediments and their accumulation as the accretionary wedge (Hók et al., 2001). The termination of the Magura Ocean lead to development of the anoxic setting and sedimentation of black shales. In the remains of the Magura Ocean, the Magura Basin was the exception with sedimentation of the syntectonic sandstones (e.g., Kováč et al., 2016).

\section{Methodology}

Quantitative interpretation of the gravity field along the seismic refraction profile CEL12 was compiled in 2-D density modelling software GM-SYS (Gravity and Magnetics Modelling system) created by Northwest Geophysical Associates, Inc. (NGA). The software was designed to calculate a gravity and/or magnetic response of the geological model, which offers user-friendly interface for interactive and intuitive creation and editing of geophysical 
models based on observed gravity and/or magnetic data. The possibility to make the process of interpretation and testing alternate admissible solution faster is due to immediate calculation of the gravity and magnetic response of the model. It is possible to interactively manipulate the geometry and change density values for every block used in a model. The software also offers various features, such as $2^{3 / 4}$-D modelling, Extended Model Size, Gravity/Magnetic Gradients, Joint Inversion/Optimalization, Seismic Bitmap (GM-SYS User's Guide for version 4.9, 2004).

GM-SYS software uses a 2-D model of the Earth, which only changes in depth (axis Z) and along the direction of the profile (axis $\mathrm{X}$ ) with the possibility to extend the model to "infinity" $( \pm 30000 \mathrm{~km})$ thus the 2 -D model represents a complex of polygons extended to infinity in the direction of axis Y (GM-SYS User's Guide for version 4.9, 2004). This allows approximating various types of geological objects, such as faults, dikes and 3-D bodies extended in the direction of axis Y (Csicsay, 2010).

Gravity and magnetic response calculation of such bodies is based on methods by Talwani et al. (1959) and Talwani and Heirtzler (1964) with algorithm after Won and Bevis (1987). $2^{1 / 2}$-D calculation is based on formula by Rasmussen and Pedersen (1979). Methods patented by NGA were used to increase effectivity and speed of calculations and to better optimise the interactive interface. GM-SYS inversion implements the Marqardt inverse algorithm (Marqardt, 1963) and its application to gravimetry and magnetics was introduced by U.S. Geological Survey.

\section{Input data}

Gravity data, the key data type for creating a 2-D density model, were compiled from the gravity map of the southern part of Poland (Królikowski and Petecki, 1995; Bielik et al., 2006). Complete Bouguer Anomaly attains here values from -46.8 to $-72.1 \mathrm{mGal}\left(1 \mathrm{mGal}=10^{-5} \mathrm{~ms}^{-2}\right)$. At the beginning of the profile, there is an increasing trend of values from the initial $-68 \mathrm{mGal}$ up to $-50 \mathrm{mGal}$ at the $110 \mathrm{~km}$ distance. The highest values (more than $-50 \mathrm{mGal})$ are at about the centre of the profile (111-th to 140 -th $\mathrm{km}$ from the beginning of the profile), followed by rapid decrease of values towards the end of the profile, with values of about $-68.5 \mathrm{mGal}$ and less, which are 
the lowest on the CEL12 profile.

Heights of the topographic suface were taken from GTOPO30 (Gesch et al., 1999) for $192 \mathrm{~km}$ long profile with a step of $1 \mathrm{~km}$. Since our model is 2-D, it is important for the assessment of the results (Zeyen et al. 2002) to have some measure of the $3 \mathrm{D}$ variability of the input data. For this reason, we show the topography in Figures 3 and 4 not only along the profile CEL12 but in a stripe of $25 \mathrm{~km}$ width to both sides of the profile for topography. Higher topography is located in the western part of the profile with the highest value of $850 \mathrm{~m}$ above sea level (around 10-th $\mathrm{km}$ ). The lowest point of the profile is $350 \mathrm{~m}$ above sea level $(\sim 120$-th $\mathrm{km})$.

Comparing the gravity and topography (Fig. 3) we can say that there is a good (negative) correlation between them. Generally, the higher topography correlates with lower values of the Complete Bouguer Anomalies. This fact can indicate a compensation of topography in depth, e.g. by the Moho discontinuity (Bielik, 2000). And vice-versa, the section with the lowest topography has the highest observed gravity values, which can indicate the elevation of Moho. However, this assumption may not be applicable everywhere.

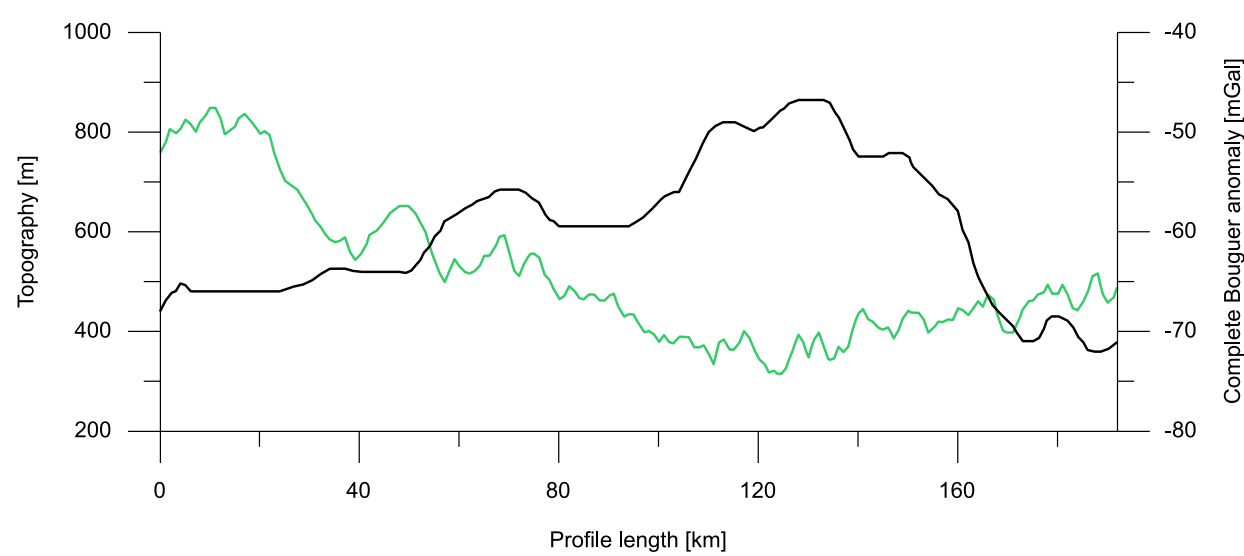

Fig. 3. Graph comparing the gravity (black line) and topography (green line) data.

The CEL12 seismic refraction profile (Fig. 4) compiled by Janik et al. (2011) was used to define input data regarding geometry and position of density anomalous bodies, which are approximated by polygons in the GMSYS software. The length of this profile is $192 \mathrm{~km}$ and its vertical section 
extends down to $80 \mathrm{~km}$ in depth. The longitudinal seismic wave velocities $v_{p}$ change between 2.73 and $8.38 \mathrm{~km} \mathrm{~s}^{-1}$. Janik et al. (2011) divided the cross-section into several layers according to these velocities. The uppermost layer, represented by velocities up to $v_{p}=4.90 \mathrm{~km} \mathrm{~s}^{-1}$, corresponds to the sedimentary layer, the thickness of which varies from 2 to $8 \mathrm{~km}$. The velocities between $v_{p}=4.90 \mathrm{~km} \mathrm{~s}^{-1}$ and $6.10 \mathrm{~km} \mathrm{~s}^{-1}$ represent the upper part of the upper crust with thickness from $6 \mathrm{~km}$ in the western part of the profile to nearly $24 \mathrm{~km}$ in the central part. After interpretation by Janik et al. (2011), the layer with velocities $v_{p}=6.30-6.50 \mathrm{~km} \mathrm{~s}^{-1}$ represents the lower part of the upper (Penninic) crust (in the western part of the profile it reaches $16 \mathrm{~km}$ thickness). The lower crust is represented by seismic velocities between $6.50 \mathrm{~km} \mathrm{~s}^{-1}$ and $6.83 \mathrm{~km} \mathrm{~s}^{-1}$, but this range does not appear throughout the whole profile length. It is divided into two separate layers

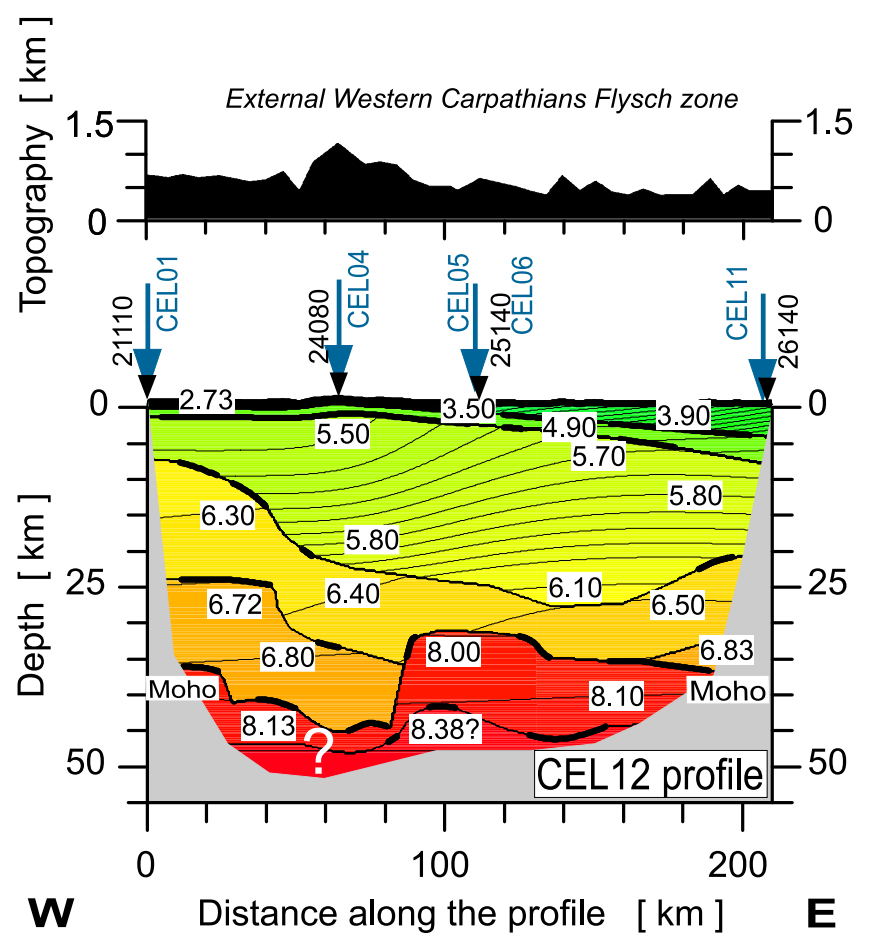

Fig. 4. The $2 \mathrm{D}$ model of seismic P-wave velocity in the crust and uppermost mantle along the CELEBRATION 2000 profile CEL12 compiled by Janik et al. (2011). Blue arrows show the positions of the CELEBRATION 200 profiles crossing the CEL12 profile. 
by the elevation of the Moho discontinuity in the central part of the profile. The uppermost part of the upper mantle is characterized by $v_{p}$ from $8.00 \mathrm{~km} \mathrm{~s}^{-1}$ up to $8.38 \mathrm{~km} \mathrm{~s}^{-1}$. The Moho depression near the central part of the profile is represented by a depth of $43 \mathrm{~km}$, which indicates the thickest crust in the Western Carpathians.

The required densities for the anomalous bodies along the profile CEL12 were obtained by transformation of $\mathrm{P}$-wave velocities $v_{p}$ to densities by formulas of Sobolev-Babeyko (Sobolev and Babeyko, 1994), ChristensenMooney (Christensen and Mooney, 1995) and Lachenbruch-Morgan (Lachenbruch and Morgan, 1990). The last formula was used to determine the densities of the anomalous layers located within the lower lithosphere (Šimonová and Bielik, 2016). The calculated density values are for: the External Western Carpathians sedimentary layer $2.49-2.59 \mathrm{~g} \mathrm{~cm}^{-3}$; the upper crust 2.26$2.82 \mathrm{~g} \mathrm{~cm}^{-3}$ (after Christensen and Mooney, 1995, or 2.64-2.69 $\mathrm{g} \mathrm{cm}^{-3}$ after Sobolev and Babeyko, 1994), with average of $2.61 \mathrm{~g} \mathrm{~cm}^{-3}$; the lower crust from $2.75 \mathrm{~g} \mathrm{~cm}^{-3}$ (or $2.76 \mathrm{~g} \mathrm{~cm}^{-3}$ after Sobolev and Babeyko, 1994) up to $3.01 \mathrm{~g} \mathrm{~cm}^{-3}$, with average value $2.89 \mathrm{~g} \mathrm{~cm}^{-3}$; the lower lithosphere from 3.34 to $3.38 \mathrm{~g} \mathrm{~cm}^{-3}$ (or $3.38 \mathrm{~g} \mathrm{~cm}^{-3}$ after Lachenbruch and Morgan, 1990), with average of $3.37 \mathrm{~g} \mathrm{~cm}^{-3}$ (ك̌imonová and Bielik, 2016).

\section{Modelling results}

On the basis of the data mentioned above we constructed an initial density model. The input parameters of the anomalous density bodies were modified by trial and error until a reasonable fit was obtained between observed gravity and calculated data (Fig. 5). The maximum average error along the profile was only $\pm 0.988 \mathrm{mGal}$, except for the beginning of the profile. These differences could be explained by a presence of near surface inhomogeneity. The final densities are shown in Fig. 5.

A general feature of the resultant density model is that the crustal thickness varies significantly along the profile CEL12. The Moho depth changes from $31 \mathrm{~km}$ to $42 \mathrm{~km}$. The crustal thickness at the beginning of the profile is about $36 \mathrm{~km}$, and to the east it gradually increases to a depth of $43 \mathrm{~km}$ (at 60 -th $\mathrm{km}$ of profile). This thickness of the crust is the largest in the whole area of the Western Carpathians. At 75 -th $\mathrm{km}$ of profile the Moho 
boundary rises sharply to a depth of only $31 \mathrm{~km}$ and in the interval from 80 -th to 110 -th $\mathrm{km}$ of the section only insignificant Moho elevation can be observed. Next to the east, the crustal thickness increases when it reaches $38 \mathrm{~km}$ at the end of the profile. Note that the large changes of Moho depth can be observed in a relatively short interval $(190 \mathrm{~km})$ and in only a single tectonic unit - the External Western Carpathian Flysch zone. This is a significant finding.

The crust consists of four anomalous density layers: sedimentary, upper part of the upper crust, lower part of the upper crust and lower crust.

The sedimentary layer consists of two parts. The maximum thickness of the western part with $2.40 \mathrm{~g} \mathrm{~cm}^{-3}$ density reaches about $6 \mathrm{~km}$ and its thickness thins out significantly to the east. The eastern part of the sedimentary layer is characterized by thickness, which varies from 0 to $10 \mathrm{~km}$.
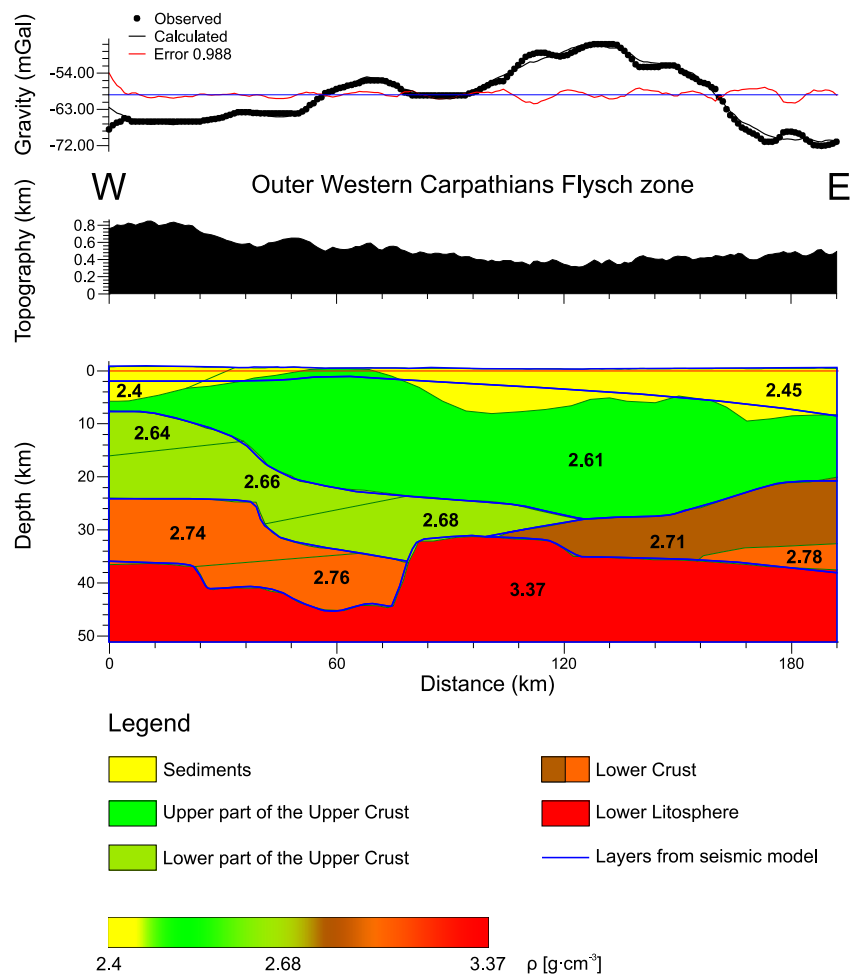

Fig. 5. 2-D density model of the profile CEL12. Blue lines show the seismic model used as a starting model. 
The upper crust consists of two layers. The upper part of the upper crust is represented by lower average density $2.61 \mathrm{~g} \mathrm{~cm}^{-3}$ and its thickness varies from about $2 \mathrm{~km}$ up to $20 \mathrm{~km}$. The lower part of the upper crust dips in the direction from west to east. In the same direction, its average density is also increasing from $2.64 \mathrm{~g} \mathrm{~cm}^{-3}$ to $2.68 \mathrm{~g} \mathrm{~cm}^{-3}$. The depth of the boundary between them varies from $7.5 \mathrm{~km}$ (0-th $\mathrm{km}$ of the profile) up to $28 \mathrm{~km}$ (120-th $\mathrm{km}$ of the profile). The western part of the lower crust is represented by average density $2.74-2.76 \mathrm{~g} \mathrm{~cm}^{-3}$ and its thickness varies from 8 to $12 \mathrm{~km}$. The upper boundary of this layer varies from $24 \mathrm{~km}$ up to $34 \mathrm{~km}$. The eastern part of the lower crust has average density $2.71-2.78 \mathrm{~g} \mathrm{~cm}^{-3}$. Its thickness at the end of the profile reaches $17 \mathrm{~km}$, while towards the west this part of the lower crust thins out and at the 96 -th $\mathrm{km}$ of the profile reaches thickness of $0 \mathrm{~km}$.

The lower lithosphere (uppermost part of the upper mantle) is characterized by average density of $3.37 \mathrm{~g} \mathrm{~cm}^{-3}$.

\section{Discussion and Conclusion}

The orientation of the profile CEL12 in terms of 2-D modelling is not ideal as it is nearly parallel to the course of the External Western Carpathian unit (Fig. 2). In spite of this, the agreement between the results of seismic and gravimetric modelling is excellent.

The results of 2-D density modelling confirmed the seismic interpretation along the profile CEL12, which has discovered that the crustal thickness over the profile interval from 24-th $\mathrm{km}$ to 72 -nd $\mathrm{km}$ reaches more than $42 \mathrm{~km}$. Based on the knowledge about the depth of the Moho discontinuity (e.g. Janik et al., 2011; Bielik et al., 2018), it is known that this crustal thickness is the largest in the whole area of the Western Carpathians.

The results of 2-D density modelling show clearly that significant changes can be expected in the thicknesses of the crust, sedimentary layer, upper and lower crust not only along and across the Western Carpathians but also within its individual tectonic units of which they are composed.

Acknowledgements. This work was supported by the Slovak Grant Agency VEGA, grants No. 1/0141/15, 2/0042/15, and APVV grants No. APVV-16-0146, APVV16-0482. 


\section{References}

Alasonati Tašárová Z., Afonso J. C., Bielik M., Götze H. J., Hók J., 2009: The lithospheric structure of the Western Carpathian-Pannonian Basin region based on the CELEBRATION 2000 seismic experiment and gravity modeling. Tectonophysics, 475, 454-469.

Alasonati Tašárová Z., Fullea J., Bielik M., Środa P., 2016. Lithospheric structure of Central Europe: Puzzle pieces from Pannonian Basin to Trans-European Suture Zone resolved by geophysical-petrological modelling. Tectonics, 35, 1-32, doi: 10.1002/2015TC003935.

Behm M., Brückl E., Mitterbauer U., 2007: A New Seismic Model of the Eastern Alps its Relevance for Geodesy and Geodynamics. VGI Österrreichische Zeitschrift für Vermessung \& Geoinformation, 2, 121-133.

Bielik, M., 2000: Study of the gravity field in the Tibetan Plateau. Contributions to Geophysics \& Geodesy, 30, 4, 343-358.

Bielik M., Kloska K., Meurers B., Švancara J., Wyberaniec S., Fancsik T., Grad M., Grand T., Guterch A., Katona M., Królikowski C., Mikuška J., Pašteka R., Petecki Z., Polechońska O., Ruess D., Szalaiová V., Šefara J., Vozár J., 2006: Gravity anomaly map of the CELEBRATION 2000 region. Geologica Carpathica, 57, 3, $145-156$.

Bielik M., Makarenko I., Csicsay K., Legostaeva O., Starostenko V., Savchenko A., Šimonová B., Dérerová J., Fojtková L., Pašteka R., Vozár J., 2018: The refined Moho depth map in the Carpathian-Pannonian region. Contributions to Geophysics and Geodesy, 47, 2, 179-190, doi: 10.2478/congeo-2018-0007.

Brückl E., 2011: Lithospheric Structure and Tectonics of the Eastern Alps - Evidence from New Seismic Data. In: Tectonics, Ed.: Closson D. InTech, Available from: http://www. intechopen.com/books/tectonics/lithospheric-structure-and-te ctonics-of-the-eastern-alps-evidence-from-new-seismic-data.

Brückl E., Behm M., Decker K., Grad M., Guterch A., Keller G. R., Thybo H., 2010: Crustal structure and active tectonics in the Eastern Alps. Tectonics, 29, 1-17.

Christensen N. I., Mooney W. D., 1995: Seismic velocity structure and composition of the continental crust: A global view. Journal of Geophysical Research 100, B7, 9761-9788.

Csicsay K., 2010: Two-dimensional and three-dimensional itegrated iterpretation of gravity field within the frame of international project CELEBRATION 2000. PhD. thesis, Faculty of Natural Sciences of Comenius University, Bratislava, 155 (in Slovak).

Csontos L., Nagymarosy A., Horváth F., Kováč M., 1992: Tertiary evolution of the IntraCarpathian area: a model. Tectonophysics, 208, 221-241.

Dérerová J., Zeyen H., Bielik M., Salman K., 2006. Application of integrated geophysical modeling for determination of the continental lithospheric thermal structure in the eastern Carpathians. Tectonics, 25, 3, 1-12. TC3009, doi: 10.1029/2005TC001883.

Gemmer L., Houseman G. A., 2007: Convergence and extension driven by lithospheric gravitational instability: evolution of the Alpine-Carpathian-Pannonian system. Geophysical Journal International, 168, 1276-1290. 
Gesch D. B., Verdin K. L., Greenlee S. K., 1999: New land surface digital elevation model covers the Earth. Eos Trans. AGU, 80, 69-70. [online] [cit. 2018-04-03]. Available from: https://www.ngdc.noaa.gov/mgg/topo/report/s7/s7Bi.html.

GM-SYS ${ }^{\circledR}, 2004$ : User's Guide for version 4.9. Northwest Geophysical Associates, Inc., Corvallis, 101.

Grad M., Guterch A., Keller G. R., Janik T., Hegedűs E., Vozár J., Slaczka A., Tiira T., Yliniemi J., 2006: Lithospheric structure beneath trans-Carpathian transect from Precambrian platform to Pannonian Basin: CELEBRATION 2000 seismic profile CEL05. J. Geophys. Res., 111, 1-23.

Grinč M., Zeyen H., Bielik M., Plašienka D., 2013. Lithospheric structure in Central Europe: Integrated geophysical modeling, J. Geodyn., 66, 13-24, doi: 10.1016/j .jog. 2012.12.007.

Guterch A., Grad M., Špičák A., Brückl E., Hegedüs E., Keller G. R., Thybo H., CELEBRATION 2000, ALP 2002, SUDETES 2003 working groups 2003a: Special contributions: An overview of recent seismic refraction experiments in central Europe. Studia Geophysica et Geodaetica, 47, 3, 659-669.

Guterch A., Grad M., Špičák A., Brückl E., Hegedűs E., Keller G. R., Thybo H., CELEBRATION 2000, ALP 2002, SUDETES 2003 working groups, 2003b: Special contributions: An overview of recent seismic refraction experiments in central Europe. Studia Geophysica et Geodaetica, 47, 3, 651-657.

Hók J., Kahan Š., Aubrecht R., 2001: Geology of Slovakia. 1st ed., 34-36. (in Slovak), ISBN 80-223-1592-3.

Hók J., Šujan M., Šipka F., 2014: Tectonic division of the Western Carpathians: an overview and a new approach. Acta Geologica Slovaca, 6, 2, 135-143.

Hrubcová P., Środa P., Špičák A., Guterch A., Grad M., Keller G. R., Brückl E., Thybo H., 2005: Crustal and uppermost mantle structure of the Bohemian Massif based on CELEBRATION 2000 data. J. Geophys. Res., 110, 1-21.

Hrubcová P., Środa M., Grad M., 2010: From the Variscan to the Alpine Orogeny: crustal structure of the Bohemian Massif and the Western Carpathians in the light of the SUDETES 2003 seismic data. Geophysical Journal International, Geodynamics and tectonics, 183, 2, 611-633, doi: 10.1111/j.1365-246X.2010.04766.x.

Janik T., Grad M., Guterch A., Vozár J., Bielik M., Vozárová A., Hegedűs E., Kovács C. A., Kovács I., CELEBRATION 2000 Working Group, 2011: Crustal structure of the Western Carpathians and Pan-nonian Basin System: seismic models from CELEBRATION 2000 data and geological implication. Journal of Geodynamics, 52, 2, 97-113.

Jones A. G., Plomerová J., Korja T., Sodoudi F., Spakman W., 2010. Europe from the bottom up: A statistical examination of the central and northern European lithosphere-asthenosphere boundary from comparing seismological and electromagnetic observations. Lithos, 120, 1-2, 14-29, doi: 10.1016/j.lithos.2010.07.013.

Kaban M. K., Tesauro M., Cloetingh S., 2010. An integrated gravity model for Europe's crust and upper mantle, Earth Planet. Sci. Lett., 296, 195-209. doi : 10.1016/j.ep sl.2010.04.041. 
Knapp J. H., Knapp C. C., Raileanu V., Matenco L., Mocanu V., Dinu C., 2005: Crustal constraints on the origin of mantle seismicity in the Vrancea Zone, Romania: The case for active continental lithospheric delamination. Tectonophysics, 410, 311-323.

Konečný V., Kováč M., Lexa J., Šefara J., 2002: Neogene evolution of the CarpathoPannonian region: an interplay of subduction and back-arc diapiric uprise in the mantle. European Geosciences Union, Stephan Mueller Special Publication Series, 1, 105-123.

Kováč M., Plašienka D., Soták J., Vojtko R., Oszczypko N., Less G., Ćosović V., Fügenschuch B., Králiková S., 2016: Paleogene palaeogeography and basin evolution of the Western Carpathians, Northern Pannonian domain and adjoining areas. Global and Planetary Change, 140, 9-27.

Królikowski C., Petecki Z., 1995: Gravimetric atlas of Poland. Państwowy Instytut Geologiczny, Warszawa.

Lachenbruch A. H., Morgan P., 1990: Continental extension, magmatism and elevation; formal relations and rules of thumb. Tectonophysics, 174, 39-62.

Malinowski M., Guterch A., Narkiewicz M., Probulski J., Maksym A., Majdański M., Środa P., Czuba W., Gaczyński E., Grad M., Janik T., Jankowski L., Adamczyk A., 2013: Deep seismic reflection profile in Central Europe reveals complex pattern of Paleozoic and Alpine accretion at the East European Craton margin. Geophysical Research Letters, 40, 1-6.

Malinowski M., Środa P., Grad M., Guterch A., CELEBRATION 2000 Working Group, 2009: Testing robust inversion strategies for three-dimensional Moho topography based on CELEBRATION 2000 data. Geophys. J. Int., 179, 1093-1104.

Marqardt D. W., 1963: An algorithm for least squares estimation of non-linear parameters. Journal of the Society for Industrial and Applied Mathematics, 11, 431-441.

Miš́k M., Chlupáč I., Cicha I., 1985: Stratigraphic and historical geology. 1st ed., SPN Bratislava, 304-44 (in Slovak).

Nemčok M., Pospíšil L., Lexa J., Donelick R. A., 1998: Tertiary subduction and slab break-off model of the Carpathian-Pannonian region. Tectonophysics, 295, 307340.

Oszczypko N., 2004: The structural position and tectonosedimentary evolution of the Polish Outer Carpathian. Przeglad Geologiczny, 52, 2, 65-82.

Oszczypko N., Ślaczka A., Oszczypko-Clowes A., Olszewska B. 2015: Where was the Magura Ocean. Acta Geologica Polonica, 65, 3, 319-344.

Plomerová J., Babuška V., 2010: Long memory of mantle lithosphere fabric - European LAB constrained from seismic anisotropy. Lithos, 120, 131-143.

Rasmussen R., Pedersen L. B., 1979: End corrections in potential field modeling. Geophysical Prospecting, 27, 4, 749-760.

Ryłko W., Tomaś A., 2005: Basement structure below the West-Carpathian-East Carpathian orogen junction (eastern Poland, north-eastern Slovakia and western Ukraine). Geologica Carpathica, 56, 1, 29-40.

Šimonová B., Bielik M., 2016: Determination of rock densities in the Carpathian-Pannonian Basin Litosphere: based on the CELEBRATION 2000 experiment. Contributions to Geophysics and Geodesy, 46, 4, 269-287. 
Sobolev S. V., Babeyko A. Y., 1994: Modeling of mineralogical composition, density and elastic wave velocities in anhydrous magmatic rocks. Surveys in Geophysics, 15, 5, 515-544.

Środa P., Czuba W., Grad M., Gutterch A., Tokraski A. K., Janik T., Rauch M., Keller G. R., Hegedűs E., Vozár J., CELEBRATION 2000 Working Group, 2006: Crustal and upper mantle structure of the Western Carpathians from CELEBRATION 2000 profiles CEL01 and CEL04: seismic models and geological implications. Geophys. J. Int., 167, 737-760.

Talwani M., Heirtzler J. R., 1964: Computation of magnetic anomalies caused by twodimensional bodies of arbitrary shape. In: Parks G. A. (Ed.), Computers in the mineral industries, Part 1: Stanford Univ. Pub., Geological Sciences, 9, 464-480.

Talwani M., Worzel J. L., Landisman M., 1959: Rapid gravity computations for two dimensional bodies with application to the Mendocino submarine fracture zone. Journal of Geophysical Research, 64, 49-59.

Tesauro M., Kaban M. K., Cloetingh S., 2008. EuCRUST-07: A new reference model for the European crust. Geophys. Res. Lett., 35, L05313, doi: 10.1029/2007GL032244.

Won I. J., Bevis M. G., 1987: Computing the gravitational and magnetic anomalies due to a polygon: Algorithms and Fortran subroutines. Geophysics, 52, 232-238.

Zeyen H., Dérerová J., Bielik M., 2002. Determination of the continental lithosphere thermal structure in the Western Carpathians: integrated modelling of surface heat flow, gravity anomalies and topography. Physics of the Earth and Planetary Interiors, 134, 89-104. 